\title{
In vitro Efficacy of Systemic Fungicides against $A$. macrospora causing Leaf Spot in Bt Cotton
}

\author{
I.D. Raut, C.V. Ambadkar* and K.D. Navgire \\ Department of Plant Pathology, College of Agriculture, Parbhani, Vasantrao Naik \\ Marathwada Krishi Vidyapeeth, Parbhani, India \\ *Corresponding author
}

A B S T R A C T

\begin{abstract}
Keywords
Bt cotton, Leaf spot,

Alternaria

macrospora,

Fungicides

Article Info

Accepted:

10 December 2018

Available Online:

10 January 2019

Eight systemic fungicides viz., Propiconazole, Hexaconazole, Difenconazole, Tebuconazole, Benomyl, Carbendazim, Tridemoph and Thiophanate methyl (each @ 500 and 1000 ppm concentration) were evaluated in vitro against Alternaria macrospora causing leaf spot of cotton. All the treatments significantly inhibited mycelial growth of Alternaria macrospora over untreated control. Among eight fungicides Propiconazole, Hexaconazole, Difenconazole and Tebuconazole at both (@ 500 and $1000 \mathrm{ppm}$ ) concentration inhibited 100 per cent growth of $A$. macrospora.
\end{abstract}

\section{Introduction}

Cotton (Gossypium spp.) is the most extensively cultivated commercial crop and is a major fibre crop of global importance. It is an important raw material of economy in term of both employment generation of foreign exchange and hence it is popularly known as "White gold or friendly fibre". India is the largest cotton growing country in the world. The top five producers in the world are China, India, USA, Pakistan and Uzbekistan. India occupies first rank in area and having second position in production. In India cotton is grown over an area 105 lakh hectares with production of 351 lakh bales and productivity $568 \mathrm{~kg}$ lint ha ${ }^{-1}$ (Anonymous, 2017).

Cotton crop in India is known to suffer from number of fungal, bacterial and viral diseases. Amongst the several factors responsible for reduction in yield and quality deterioration of cotton in India, diseases occupy a vital place. Amongst all the diseases of cotton Alternaria leaf blight poses an alarming situation.

Several factors responsible for reduction in yield and quality deterioration of cotton in India, diseases occupy a vital place. Amongst all the diseases of cotton Alternaria leaf blight 
poses an alarming situation, but very scanty work has been done on this disease. Considering occurrence and losses caused by Alternaria macrospora in cotton, the present investigation was carried out with a view to find out the efficacy of systemic fungicides against $A$. macrospora.

\section{Materials and Methods}

Eight systemic fungicides viz., Propiconazole, Hexaconazole, Difenconazole, Tebuconazole, Benomyl, Carbendazim, Tridemoph and Thiophanate methyl were reported effective against Alternaria macrospora causing leaf spot in cotton, were evaluated in-vitro by applying poisoned food technique (Nene and Thapliyal, 1993) and using Potato dextrose agar as basal medium. The pathogen $A$. macrospora was grown on PDA medium in petriplates for fifteen days prior to setting the experiment. Fungicide suspension was prepared in PDA by adding required quantity of fungicide to obtain the desired concentration on the basis of active ingredient and whole product present in the chemical. 20 $\mathrm{ml}$ of poisoned medium was poured in each of the sterilized Petriplates. For this $20 \mathrm{ml}$ of sterilized and cooled medium (PDA) was poured in each petriplate (90 $\mathrm{mm}$ diameter) and was allowed to solidify. A $5 \mathrm{~mm}$ disc of A. macrospora was placed at centre of the medium with the help of sterilized cork borer. For this a week old culture of A. macrospora in petridishes on sterilized PDA medium were used. Three replications for A. macrospora and control i.e. without addition of any fungicides were maintained. Petriplates were incubated at $28 \pm 2^{0} \mathrm{C}$ temperature in inverted position. Observations on radial mycelial growth and sporulation of the test fungus were recorded at $24 \mathrm{hrs}$ interval and continued till growth of the test pathogen in untreated control plate is fully covered. Per cent inhibition of the test pathogen was calculated by applying formula given by Vincent (1927) as follows.

Per cent inhibition $=\frac{\mathrm{C}-\mathrm{T}}{\mathrm{C}}$

Where,

$\mathrm{C}=$ Growth of the test fungus in untreated control plates

$\mathrm{T}=$ Growth of the test fungus in treated plates

\section{Results and Discussion}

Eight systemic fungicides viz., Propiconazole, Hexaconazole, Difenconazole, Tebuconazole, Benomyl, Carbendazim, Tridemoph and Thiophanate methyl were tested in vitro against $A$. macrospora by using poisoned food technique as described in material and methods. All eight systemic fungicides evaluated in vitro were significantly found to influence mycelial growth and its corresponding inhibition of $A$. macrospora, at concentrations each @ 500 and 1000 ppm. Mycelial growth and its inhibition were found inversely and directly proportional, respectively to concentrations of the fungicides tested

\section{Effect of systemic fungicides on mycelial growth of A. macrospora}

At $500 \mathrm{ppm}$ concentration, radial mycelial growth of $A$. macrospora was ranged from $00.00 \mathrm{~mm}$ to $90.00 \mathrm{~mm}$. However, the fungicides Propiconazole, Hexaconazole, Difenconazole and Tebuconazole arrested cent per cent mycelial growth. The next fungicides with significantly least mycelial growth were Benomyl (34.07 $\mathrm{mm})$, followed by Carbendazim $(44.21 \mathrm{~mm})$. The fungicides Tridemoph and Thiophanate methyl recorded comparatively maximum mycelial growth of 63.81 and $54.21 \mathrm{~mm}$, respectively.

At $1000 \mathrm{ppm}$ concentration, similar trend as that of at 500 ppm was observed and radial 
mycelial growth was ranged from $00.00 \mathrm{~mm}$ to $90.00 \mathrm{~mm}$. However, the fungicide Propiconazole, Hexaconazole, Difenconazole and Tebuconazole arrested cent per cent mycelial growth; whereas, it was significantly least with Benomyl (27.46 $\mathrm{mm})$ and Tridemoph (36.01 mm). Fungicides Thiophanatemethyl and Carbendazim recorded comparatively maximum mycelial growth of 46.12 and $40.45 \mathrm{~mm}$, respectively.

Average radial mycelial growth of the test pathogen was ranged from $00.00 \mathrm{~mm}$ (Propiconazole, Hexaconazole, Difenconazole and Tebuconazole) to $50.17 \mathrm{~mm}$ (Thiophanate methyl). However, there was none average mycelial growth with Propiconazole, Hexaconazole, Difenconazole and Tebuconazole. The fungicides with next lowest average mycelial growth were Benomyl (30.76 $\mathrm{mm})$, followed byCarbendazim $(42.23 \mathrm{~mm})$; whereas Thiophanate methyl and Tridemoph recorded comparatively maximum average mycelial growth of 24.02 and $16.98 \mathrm{~mm}$, respectively.

\section{Effect of systemic fungicides on mycelial growth inhibition of $A$. macrospora}

Results presented in Table 1 revealed that all systemic fungicides tested each @ 500 and 1000 ppm significantly inhibited mycelial growth of A. macrospora, over untreated control. Further, per cent mycelial inhibition was increased with increase in concentrations of the fungicides tested.

At 500 ppm, mycelial growth inhibition was ranged from 29.10 (Tridemoph) to 100 (Propiconazole, Hexaconazole, Difenconazole and Tebuconazole) per cent. However, Propiconazole, Hexaconazole, Difenconazole and Tebuconazole gave cent per cent $(100 \%)$ mycelial inhibition. The next best fungicides found were Benomyl (62.14\%), followed by Carbendazim (50.88 \%). However, Tridemoph and Thiophanate methyl were found less effective with minimum mycelial inhibition of 29.10 and 39.77 per cent, respectively.

At $1000 \mathrm{ppm}$, the trend was same as at 500 ppm and mycelial growth inhibition was ranged from 48.76 (Thiophanate methyl) to 100 per cent (Propiconazole, Hexaconazole, Difenconazole and Tebuconazole).

It was cent per cent with the fungicides Propiconazole, Hexaconazole, Difenconazole and Tebuconazole (each $100 \%$ ). In the order of merit the next most effective fungicides with significantly maximum mycelial inhibition were Benomyl (69.49\%), followed by Tridemoph (59.99 \%). However, Thiophanate methyl and Carbendazim were found less effective with minimum mycelial inhibition of 48.76 and 55.06 per cent, respectively.

Average mycelial growth inhibition recorded with the test systemic fungicides was ranged from 44.26 (Thiophanate methyl) to 100 (Propiconazole, Hexaconazole, Difenconazole and Tebuconazole) per cent.

However, it was cent per cent with Propiconazole, Hexaconazole, Difenconazole and Tebuconazole (100 \%), followed by Benomyl (65.82\%), Carbendazim (53.38\%), whereas, it was comparatively minimum with Thiophanate methyl (44.10\%) and Tridemoph (44.54\%).

Thus, all the systemic fungicides tested were found fungistatic against A. macrosporaand significantly inhibited its mycelial growth, over untreated control. However, the systemic fungicides found most effective in the order of merit were Propiconazole, Hexaconazole, Difenconazole, Tebuconazole, Benomyl, Carbendazim, Tridemophand Thiophanate methyl (Fig. 1 and 2). 
Table.1 In vitro efficacy of systemic fungicides against $A$. macrospora

\begin{tabular}{|c|c|c|c|c|c|c|c|}
\hline \multirow[t]{2}{*}{$\begin{array}{l}\text { Tr. } \\
\text { No. }\end{array}$} & \multirow[t]{2}{*}{ Treatments } & \multicolumn{2}{|c|}{$\begin{array}{l}\text { Colony Dia. } \\
*(\mathrm{~mm}) \text { at ppm }\end{array}$} & \multirow[t]{2}{*}{$\begin{array}{c}\text { Av. } \\
(\mathbf{m m})\end{array}$} & \multicolumn{2}{|c|}{$\begin{array}{c}\text { \% Inhibition* at } \\
\text { ppm }\end{array}$} & \multirow{2}{*}{$\begin{array}{c}\text { Av. } \\
\text { Inhibition } \\
(\%)\end{array}$} \\
\hline & & 500 & 1000 & & 500 & 1000 & \\
\hline $\mathbf{T}_{1}$ & $\begin{array}{l}\text { Carbendazim } 50 \\
\text { WP }\end{array}$ & 44.21 & 40.45 & 42.33 & $\begin{array}{c}50.88 \\
(45.50)\end{array}$ & $\begin{array}{c}55.06 \\
(47.90)\end{array}$ & $\begin{array}{c}53.38 \\
(46.93)\end{array}$ \\
\hline $\mathbf{T}_{2}$ & $\begin{array}{l}\text { Propiconazole } 25 \\
\text { EC }\end{array}$ & 00.00 & 00.00 & 00.00 & $\begin{array}{r}100.00 \\
(90.00)\end{array}$ & $\begin{array}{r}100.00 \\
(90.00)\end{array}$ & $\begin{array}{c}100.00 \\
(90 . .00)\end{array}$ \\
\hline $\mathbf{T}_{\mathbf{3}}$ & Hexaconazole 5 EC & 00.00 & 00.00 & 00.00 & $\begin{array}{l}100.00 \\
(90.00)\end{array}$ & $\begin{array}{r}100.00 \\
(90.00)\end{array}$ & $\begin{array}{l}100.00 \\
(90.00)\end{array}$ \\
\hline $\mathbf{T}_{4}$ & $\begin{array}{l}\text { Difenconazole } 25 \\
\text { EC }\end{array}$ & 00.00 & 00.00 & 00.00 & $\begin{array}{r}100.00 \\
(90.00)\end{array}$ & $\begin{array}{r}100.00 \\
(90.00)\end{array}$ & $\begin{array}{r}100.00 \\
(90.00)\end{array}$ \\
\hline $\mathbf{T}_{\mathbf{5}}$ & Benomyl 50 WP & 34.07 & 27.46 & 30.76 & $\begin{array}{c}62.14 \\
(52.02)\end{array}$ & $\begin{array}{c}69.49 \\
(56.47)\end{array}$ & $\begin{array}{c}65.82 \\
(54.22)\end{array}$ \\
\hline $\mathbf{T}_{6}$ & $\begin{array}{l}\text { Tebuconazole } 25 \\
\text { EC }\end{array}$ & 00.00 & 00.00 & 00.00 & $\begin{array}{l}100.00 \\
(90.00)\end{array}$ & $\begin{array}{l}100.00 \\
(90.00)\end{array}$ & $\begin{array}{l}100.00 \\
(90.00)\end{array}$ \\
\hline $\mathbf{T}_{7}$ & $\begin{array}{l}\text { Thiophanate } \\
\text { methyl } 70 \mathrm{WP}\end{array}$ & 54.21 & 46.12 & 50.17 & $\begin{array}{c}39.77 \\
(39.09)\end{array}$ & $\begin{array}{c}48.76 \\
(44.28)\end{array}$ & $\begin{array}{c}44.26 \\
(41.70)\end{array}$ \\
\hline $\mathbf{T}_{8}$ & Tridemoph 80 EC & 63.81 & 36.01 & 49.91 & $\begin{array}{c}29.10 \\
(32.64)\end{array}$ & $\begin{array}{c}59.99 \\
(50.76)\end{array}$ & $\begin{array}{c}44.54 \\
(41.86)\end{array}$ \\
\hline $\mathbf{T}_{9}$ & Control & 90.00 & 90.00 & 90.00 & $\begin{array}{c}00.00 \\
(00.00)\end{array}$ & $\begin{array}{c}00.00 \\
(00.00)\end{array}$ & $\begin{array}{c}00.00 \\
(00.00)\end{array}$ \\
\hline & S.E. \pm & 0.16 & 0.13 & & 0.17 & 0.15 & \\
\hline & C.D. $(P=0.01)$ & 0.61 & 0.52 & & 0.68 & 0.58 & \\
\hline
\end{tabular}

*: Mean of three replications, Dia: Diameter, Av.: Average Figures in Parentheses are arcsine transformed values

Fig.1 In vitro efficacy of systemic fungicides at $500 \mathrm{ppm}(\mathrm{A})$ and $1000 \mathrm{ppm}$ (B) on radial mycelial growth and inhibition of $A$. macrospora

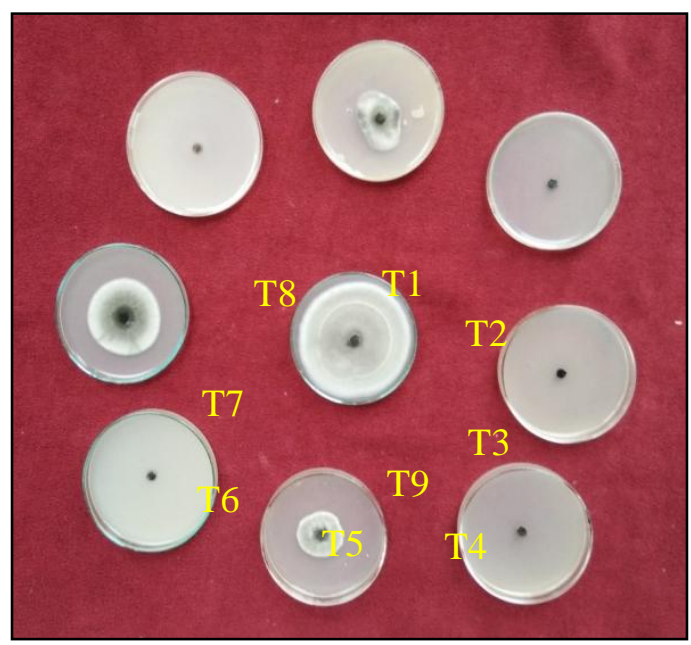

(A) 500 ppm

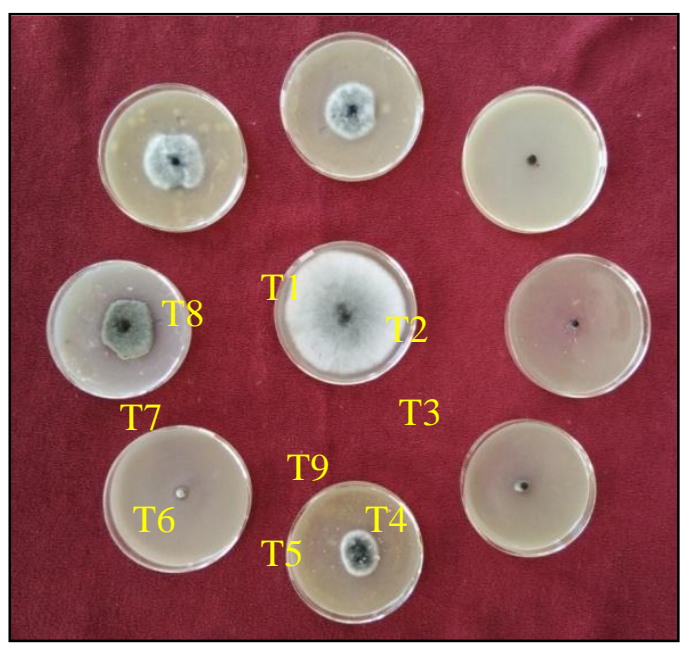

(B) 1000 ppm 
Fig.2 In vitro efficacy of systemic fungicides against $A$. macrospora

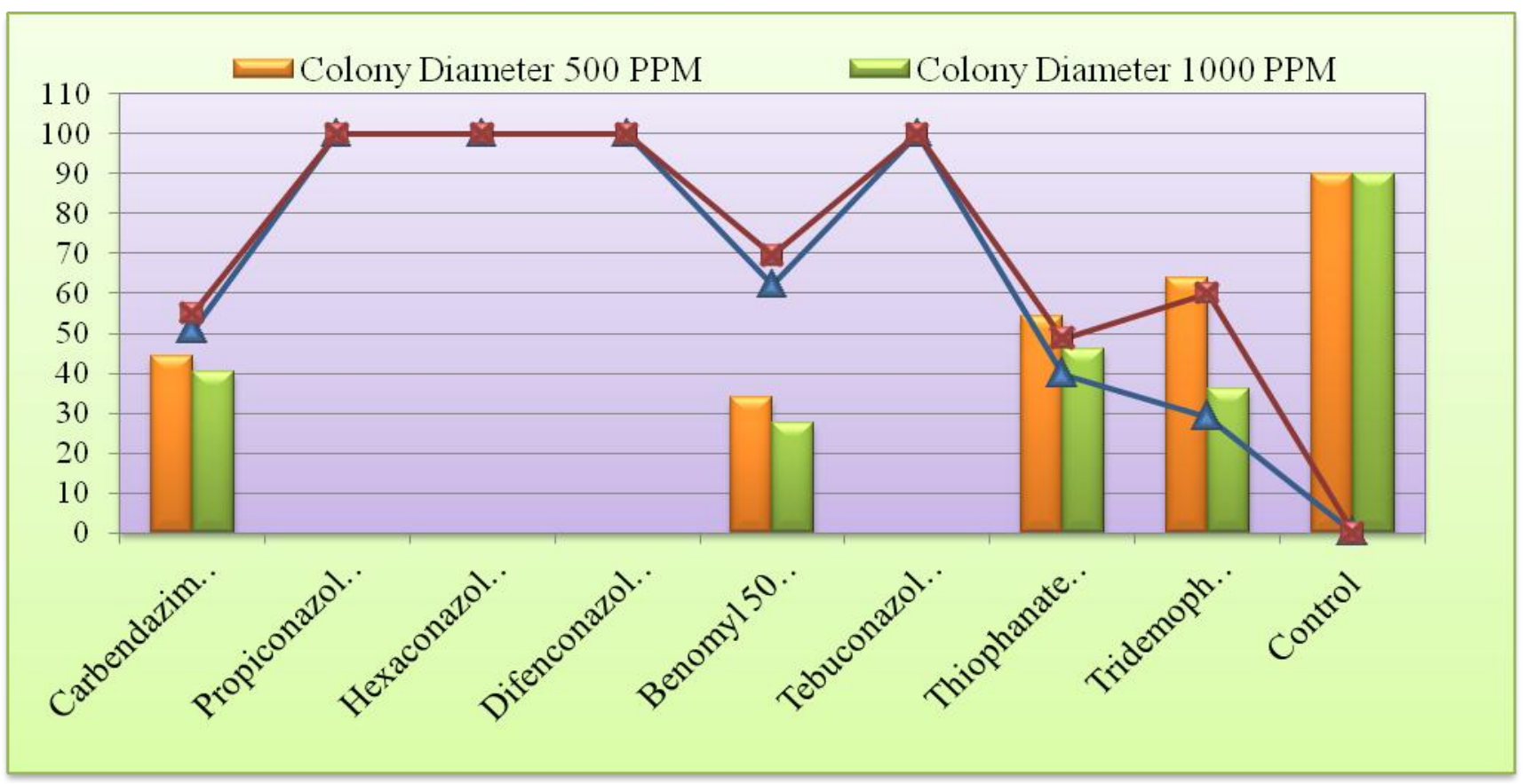

The result of present studies are found similar to the result of previous workers, viz. Patel and Chaudhary (2010) evaluated in vitro the efficacy of various fungi toxicants (each @ 200, 500 and $1000 \mathrm{ppm}$ ) against A. solani causing early blight of tomato and reported that Difenconazole and Thiphanate methyl caused highest mycelia growth inhibition. Yadav et al., (2013) evaluated six systemic fungicides at 50,100, 250 and $500 \mathrm{ppm}$, in vitro against Alternaria porri causing purple blotch of onion and reported that Hexaconazole inhibited the growth completely at higher concentration of 250 and $500 \mathrm{ppm}$ and caused significantly highest mean mycelia inhibition $(98.21 \%)$, followed by the Propiconazole (97.32\%), Difenoconazole (91.23\%), Tebuconazole (89.77\%), Thiophanate methyl $(18.41 \%)$ and Carbendazim (10.97\%). Similar results with regard to inhibition of Alternaria spp. causing leaf spot in different crops were reported by Yadav et al., (2013), Apet et al., (2014), Berman et al., (2015) and Pansambal et al., (2015).

\section{References}

Anonymous (2017). Annual progress report of cotton. www.cab.com.

Apet, K. T., Jagdale, J. S., Mirza, F. N., Wagh, S. S. and Chavan, P. G. (2014).Effect of various culture media on cultural and morphological characteristics of Alternaria alternata. Trends Biosci., 7(21): 3383-3385

Berman, H., Roy, A. and Das, S. K. (2015). Evaluation of plant products and antagonistic microbes against leaf blight (Alternaria alternata), a devastating pathogen of tomato. Trends Biosci., 85(13): 1908-1913.

Nene, Y. L. and Thapliyal, P. N. (1993). Fungicides in plant disease control ( $3^{\text {rd }}$ ed.) Oxford, IBM Publishing Co., New Delhi, pp. 331.

Pansambal, S. A., Raut, R. A. and Mahajan P. J. (2015). Bio-efficacy of different fungicides against Alternaria leaf spot of okra caused by Alternaria 
chlamydospora. Trends Biosci.,8(20): 5583-5587

Patel, R. L. and Chaudhary, R. F. (2010).Management of Alternaria solani causing early blight of tomato with fungicides. J. Pl. Dis. Sci., 5(1): 65-67.

Vincent, J. M. (1927). Distortion of fungal hyphae in the presence of certain inhibitors. Nature. 59: 850.

\section{How to cite this article:}

Raut, I.D., C.V. Ambadkar and Navgire, K.D. 2019. In vitro Efficacy of Systemic Fungicides against A. macrospora causing Leaf Spot in Bt Cotton. Int.J.Curr.Microbiol.App.Sci. 8(01): 1314-1319. doi: https://doi.org/10.20546/ijcmas.2019.801.140 